\title{
The Effect of Electronic Service Quality on Customers Behavioral Intentions
}

\author{
Maliheh Teimouri (Corresponding author) \\ Master of Information Technology Management \\ University of Sistan and Baluchestan, Iran \\ E-mail: Moonlight.361@gmail.com
}

Nour Mohamad Yaghoubi

Department of Management, School of management and Accounting

University of Sistan and Baluchestan, Zahedan, Iran

E-mail: yaghoobinor@yahoo.com

Mehdi Kazemi

Department of Management, School of management and Accounting

University of Sistan and Baluchestan, Zahedan, Iran

E-mail: mehdykazemi@gmail.com

Received: February 23, $2012 \quad$ Accepted: March 6, $2012 \quad$ Published: April 1, 2012
doi:10.5539/ijms.v4n2p179 $\quad$ URL: http://dx.doi.org/10.5539/ijms.v4n2p179

\begin{abstract}
Considering the increasing role of service organizations in various areas of economic and the importance of quality in competitive areas, service quality is known as one of the strategic levers and key axes in competition scene. In this way and in order to evaluate and improve their service quality, service organizations must identify their customers' needs and expectations, investigate the confidence and satisfaction level of their customers at specified period of time, and do their best to improve their services. If organizations can provide, retain, and increase customer satisfaction and confidence, they will be equally successful. Investigating the relationship between electronic service quality and customers behavioral intentions was the aim of this study; electronic satisfaction and confidence were studied as intermediate variables. This is an applied research and in terms of data collection method, the study is descriptive. To assess data, a 5-option Likert type questionnaire was used. Statistical population includes customers of electronic banking service in Tejarat Bank of Zahedan and sample size was estimated as 275 individuals selected by simple random sampling method. Structural equation modeling and LISREL software were used for data analysis. Results show that variables of confidence and satisfaction play mediator role in relation to electronic service quality and behavioral intentions; they also have significant positive effect on customer behavioral intentions.
\end{abstract}

Keywords: Electronic service quality, Electronic satisfaction, Electronic confidence, Customers' behavioral intentions, Website

\section{Introduction}

Changes in people's life in different communities due to the Internet, electronic services, and ICT have led to significant rapid distribution of new concepts, technologies and services. Most experienced and successful companies in E-commerce have understood that low price and mere presence on the Web are not the only success factors, but providing high-quality electronic service is the important one. So the main future challenge for companies in this area will be providing service quality. However, providing customer satisfaction, particularly in the area of services, depends on qualified services. Based on several research results in service organizations, service quality is the most important factor in increasing customer satisfaction and confidence level and 
consequently, customer loyalty. Financial firms have well understood that retaining current customers is more profitable than attracting new ones. Therefore, marketing units have prevented spending time and money on causeless advertisements and focused on techniques for customer retention. Market research has shown that purchase and even financial performance of service quality have significant effect on customer satisfaction, customer loyalty, customer retention, and decision making in company. Thus, in order to build confidence and loyalty in customers as well as retaining them, internet retailers should focus on high quality of electronic services before, during and after the exchange.

\section{Research Literature}

\subsection{Electronic Service Quality}

Quality in electronic services is defined as a 7-dimensional phenomenon which is classified in two scales: (a) high quality of main electronic services, (b) improvement.

1) High quality of main electronic services: It consists of efficiency, reliability, order supplying, and personal privacy:

- Efficiency refers to customers' ability in visiting website, finding appropriate products and information, and controlling them with minimum efforts.

- Order supplying integrates accuracy of service promises, having sufficient stock of products, and product delivery in promised time period.

- Reliability is related to technical performance of Website and the extent to which it is available 24 hours a day and works well.

- Personal privacy includes ensuring that the data related to consumer's buying behavior do not share as well as credit card information of online buyer is stored securely.

2) Improvement: It includes:

- Accountability measures capacity and ability of company in preparing return goods management mechanism, agreement for online guarantees, and providing appropriate information for customers when problems occur.

- Compensation which includes reimbursement of part of money for transporting returns goods and managing them.

- Contact refers to customers' need to have alive and urgent talk by phone or with an online representative (Wang, 2003: 1).

Although establishing electronic service quality standards is in its early stages, companies have created several types of e-service quality determinants. Each company uses these criteria individually. Service quality determinants are related to the seven dimensions of service quality.

\subsection{Customers Behavioral Intentions}

The real value of service quality is based on its requirements in decision making. Researchers have been mentioned distinction between defensive and aggressive marketing policies and tactics. Aggressive marketing efforts refer to attract new customers through investment in service quality. But service quality is just one of marketing variables which affects customers' decision for consumption. So, just investment in service quality does not guarantee attracting new customers (Zahourieck \& Raset, 1993: 214).

Marketing efforts focus on retaining existing customers rather than attracting new ones. Interesting and remarkable discussions are proposed toward such strategic actions. The main focus of these discussions is economic necessity. For example, decreasing customer referral has effect on corporate profit in traditional as well as electronic conditions. This is due to the fact that attracting new customers for replacement of lost customers is expensive because of two reasons: First, the cost of attracting new customers is high and it is more than traditional sales channels in e-commerce; second, it needs passing time for new customers being able to be profitable. Indeed, this period is at least estimated two to three years at web condition (Reichheld \& Schefler, 1993: 214).

\subsection{Electronic Satisfaction}

Electronic satisfaction means customer satisfaction according to his/her previous buying experience from electronic commerce point of view (Taylor, 1995: 41).

Electronic satisfaction is the customer satisfaction level toward web design as well as comfort and safety of purchasing (Oliver, 1989: 29). 
Electronic satisfaction means preferring goods or services of an electronics firm during shopping rather than its competitors (Oliver, 1999: 110).

Electronic satisfaction is customer satisfaction level toward supports for receiving and sending goods or services orders, after sales services, the price of goods or services, quality of website content, website speed, reliability of website, ease of using website, and website security- financially and personal privacy (Lee, 2001: 75).

\subsection{Electronic Confidence}

\subsubsection{The definition of Confidence (Trust)}

Falcon and Kastefranchy (2001) stated that confidence is essentially a subjective and mental state; a complex mental state of factor $\mathrm{X}$ toward another factor $\mathrm{Y}$ about the action / behavior associated with the results (Castaldo, 2007: 250).

$\mathrm{Lu}$ (1979), Grabner and Kruter (2002) basically consider confidence as a mechanism to reduce social complexity and perceived risk of transactions by increasing anticipation of positive output and perceived ensure about the expected behavior of the person who is trusted (Woo \& Chen, 2005: 788).

\subsubsection{The definition of Online Confidence (Trust)}

Online confidence comes up through positive interaction of customers and online seller. When customers interacting with a website feel comfortable and relaxed, they tend to increase their confidence to the website and feel less fear and uncertainty. According to the research and existing models about online confidence, specific technology factors that affect online confidence include:

- Website quality (system quality and information quality)

- Website structural warranty

- Website normal positioning

Online confidence can be successful when the relationship between two people is honest and transparent. The honesty and transparency are key criteria for assessing the reliability of custodians (Koufaris and Hampton- Sosa, 2004: 380).

In practice, numerous studies have been made to investigate electronic confidence. For example, Theo et al. (2007), Boulianne et al. (2009), Benamati et al. (2009), Gao et al. (2010) have done some researches on online confidence.

\section{Research History}

Several studies have been done in the field of electronic service quality and customer behavioral intentions. Some of these studies are: Youngwa L., Kenneth A. Kozar, "investigating the effect of website quality on e-business success" (2006); Trocchia, J.P. \&Janda, S., "how do consumers evaluate internet retail service quality?" (2003); Zeithaml, V.A., "service quality, profitability \& the economic worth of customers: what we know and what we need to learn" (2000); Keum, H., Cho, J. "A model of consumer behaviors in electronic commerce: trust, information search, and internet shopping" (2003); Parasuraman, A., Zeuthaml, V.A. \& Berry, L.L., "a multiple item scale for measuring consumer perceptions of service quality" (1988); Oliver, R. L. "whence consumer loyalty?" (1999); Gounaris S., Serjios D., \& Vlasis S., "an examination of the effects of service quality and satisfaction on costomers behavioral intentions in e-shopping" (2010); Casalo, L., Flavin , C. \& Guinalio, M., "the role of perceived usability, reputation, satisfaction and customer familiarity on the website loyalty formation process" (2007).

In association with electronic satisfaction and confidence, it also can be pointed out to researches of Garbarino \& Johnson (1999); Szymanski \& Hise (2000); Boulianne \& Cho (2009); Castaldo (2007); Yaobin \& Tao (2007); Jarvenpaa, Tractinsky \& Vitale (2000); Chen \& barnes (2007) \& Koehn (2003).

\section{Research Conceptual Model}

To do scientific and systematic research, a scientific and theoretical framework is needed which is called conceptual model. Because Spyrus Guanarys' model includes all variables studied in this study, it has been used in this study. Moreover, considering the importance of confidence in research history, it was also studied in research conceptual model which is shown in Figure 1.

\section{Research Hypotheses}

- Electronic service quality has a positive effect on electronic service confidence.

- Electronic service quality has a positive effect on electronic service satisfaction. 
- Electronic service confidence has a positive effect on customer behavioral intentions.

- Electronic service satisfaction has a positive effect on customer behavioral intentions.

\section{Research Methodology}

This is an applied research and in terms of data collection method, the study is descriptive. It is a casual study in terms of relationship between variables. Research method is survey-type that the main advantage is its ability to generalize results. In this study, "electronic service quality" is investigated and assessed as the independent variable. The dependent variables include: electronic service confidence, electronic satisfaction, and customer behavioral intentions.

\section{Statistical Population}

Statistical population of study is all customers of electronic banking services in Tejarat Bank of Zahedan.

\section{Data Collection Method}

The validation of model is based on descriptive survey research using questionnaire. The questionnaire includes 26 questions which are divided into two quite distinct categories. The first group consists of 6 questions which are related to general profile of respondents such as gender, age, educational level, degree of familiarity with information technology, the level of using electronic services, and the level of meeting expectations by using electronic service quality. The second is included 20 questions which are designed to measure the research variables. In order to determine the importance of each model components, different questions with Likert 5-point range (fully agree, agree, no comment, disagree, totally disagree) were designed in the questionnaire. 275 customers of electronic services in Tejarat Bank Zahedan ware asked in order to confirm the model.

\section{Questionnaire Reliability}

Cronbach's alpha was used to calculate the reliability of the questionnaire in this study. The closer the index is to 1 , the more internal correlation and more homogeneous the questions are. For reliability analysis, Cronbach's alpha coefficient for questionnaire was calculated 0.79 which is more than 0.7 and indicates the reliability of the questionnaire results.

\section{Data Analysis}

The structural equation model was used in this study; so that causal relationships of customer behavioral intentions were examined through standard coefficient and a significant number using LISREL software. The hypotheses were approved or rejected based on this. Totally, first-order and second-order factor analysis (measurement model) and path analysis (structural model) were used. First and second-order factor analysis for electronic service quality and electronic service satisfaction and electronic service confidence were done for the accuracy (validity) of the questions, then through path analysis, causal relationship between electronic service satisfaction and confidence with customer behavioral intentions were evaluated. LISREL software has three basic applications: (1) confirmed factor analysis; (2) path analysis; (3) model goodness of fit (GIF). All of them were used in this study.

\section{Results}

\subsection{Statistical Description of Population}

181 of respondents were male and 94 of them were female. Most of respondents are between 20-25 years old and mostly (96 individuals) had B.A degree. In terms of familiarity with information technology, 93 individuals are moderate and the majority of respondents (101 individuals) were moderate in terms of using electronic services.

\subsection{Structural Model}

After assuring the accuracy of the measurement models (confirmed factor analysis), the main research hypotheses were examined; the model has been discussed in the following based on standard estimation (standardized coefficients) and significant coefficients (significant number). (See Figures $2 \& 3$ )

\subsection{Investigating Variables Relationships}

To investigate the relationship between variables of model, multivariate analysis or multiple regression was used; in this way, structural equations model, specifically structural models (path analysis), were applied. It should be noted that to approve or reject hypotheses, standard coefficients (Note 1) and significant numbers (Note 2) are used; confidence level is 95 and error level is 5 percent for all paths. As shown in Table 1, the effect of electronic service quality and electronic service satisfaction and electronic service confidence is significant and there is a direct relationship between them. (See Table 1) 


\subsection{Model Goodness of Fit}

Software output represents appropriate structural model (The ratio of $\chi^{2}$ to df is smaller than 3 , so $\chi^{2}$ value is low. Amount of GFI $=0.92$, AGFI $=0.90, \mathrm{RMSEA}=0.069<0.1$ also shows the structural model is appropriate). In other word, obtained data are based on the conceptual model. Considering $\beta$ coefficients, software output also shows the effect of each variable in explaining the variance of the variable scores or the main factor. The highest correlation is observed between electronic service quality and electronic service satisfaction with the regression coefficient of 1.25; the lowest correlation is between electronic service quality and electronic service confidence with the regression coefficient of -0.23 . (See Table 2)

\section{Conclusion}

Development of electronic commerce and the challenges of creating sustainable competitive advantage through the Internet necessitate better understanding of how customers find out services of electronics companies and what responds they show. In this way, factors such as perceived service quality, satisfaction, confidence, and their consequences should be examined because the website provide a different shopping environment compared with traditional channels. Thus, the objectives of this study were to examine the components of service quality, satisfaction, and confidence in Internet (online) shopping as well as to identify their direct and indirect causal relation with specific behavioral intentions of online shoppers. Focusing on the results concerning behavioral intentions of our case study, it is determined that by ensuring high quality electronic services, managers can stimulate customers' positive responses which is the key to sustainable development in internet shops. Results showed that high-level quality, satisfaction, and confidence lead to revisiting the website. It means that the foregoing factors not only cause to loyalty, but also may change traditional buyers to Internet (online) ones; so the operating costs are potentially reduced.

Research results verify some previous studies; they also are complement of some other studies in this field. In this section, we examined alignment of this study with previous researches. According to results based on first hypothesis of this research, electronic service quality has significant positive relationship with electronic service confidence which is matched with previous researches. For example, Wang and $\mathrm{Hu}$ (2009) and Yaobin and Tao (2007) have shown that the more qualified these services are provided, the more customer confidence will be. Johnson et al. (2000), Adin and Azar (2005) have shown that electronic service quality has significant positive relationship with electronic satisfaction. In fact, one way to increase the satisfaction of electronic services is providing high-quality electronic services. In the third hypothesis, the positive effect of electronic service confidence on customer behavioral intentions has been proved. By increasing confidence in electronic services, people tend to use these services more. Also in this case, Soltan et al. (2000), and Yaobin and Tao (2007) have shown that this variable has an important role in influencing motivation and behavior of customers. The studies of Lee and Lin (2005) and Zhang and Priotcock are also matched with the results obtained from the fourth hypothesis. They have evaluated the role of electronic service satisfaction in customer behavioral intentions. Based on their research, there is a strong positive relationship between these two factors. This indicates that the more satisfied customers, the more interested in using electronic services. Thus, it can be seen that the results of this study confirm many previous researches and they are matched each other.

Finally, the results of this analysis show that ensuring high quality Internet (online) presence creates a fundamental way to motivate customers so as to do Internet (online) shopping more. Development of Internet (online) selling and Internet (online) search depends on the pleasure and effectiveness of customers' perceptions about electronic shopping experience.

\section{References}

Benamati, J., Fuller, M. A., Serva, M. A., \& Baroudi, J. (2009). Clarifying the integration of trust and TAM in e-commerce environments" implications for system design and management. IEEE Transactions on Engineering Management, 1-14.

Boulianne, E., \& Cho, Ch. H. (2009). The rise and fall of web trust. International Journal of Accounting Information Systems, 10, 229-244. http://dx.doi.org/10.1016/j.accinf.2009.10.002

Casalo, L., Flavin , C., \& Guinalio, M. (2007) The role of perceived usability, reputation, satisfaction and customer familiarity on the website loyalty formation process. Computer in human behavior.

Castaldo, S. (2007). Trust in market relationships. Edward elgar publishing limited: Great Britain.

Chen, Y. H., \& Barnes, S. (2007). Initial trust and online buyer behavior. Industrial management \& data systems, 107, 1, 21-36. http://dx.doi.org/10.1108/02635570710719034 
Gao, Y., \& Wu, X. (2010). A cognitive model of trust in e-commerce: evidence from a field study in China. Journal of Applied Business Research, 26(1), 37-44.

Garbarino, E., \& Johnson, M. S. (1999). The different roles of satisfaction, trust, and commitment in customer relationships. Journal of Marketing, 63(2), 70-87. http://dx.doi.org/10.2307/1251946

Gounaris S., Serjios D., \& Vlasis S. (2010). An examination of the effects of service quality and satisfaction on costomers behavioral intentions in e-shopping. Journal of services marketing, 24, 2, 142-156. http://dx.doi.org/10.1108/08876041011031118

Jarvenpaa, S. L., Tractinsky, N., \& Vitale, M. (2000). Consumer trust in an internet store. Journal of Information Technology and Management, 1, 45-71. http://dx.doi.org/10.1023/A:1019104520776

Keum, H., \& Cho, J. (2003). A model of consumer behaviors in electronic commerce: trust, information search, and internet shopping. The Communication and Technology Division of the International Communication Association Annual Conference. San Diego. CA, p 23-27.

Koehn, D. (2003). The nature of and conditions for online trust. Journal of Business Ethics, 43(1), 3-19. http://dx.doi.org/10.1023/A:1022950813386

Koufaris, M., \& Hampton-Sosa, W. (2004). The development of initial trust in an online company by new customers. Journal of Information and Management, 41, 377-397.

Lee, G. G., \& Lin, H. F. (2005). Customer perceptions of e-service quality in online shoping. International journal of retail \& disteribusion management, 33, 2, 61-76.

Lee, M.K.O., and Turban, E. (2001). A trust model for consumer internet shopping. International Journal of Electronic Commerce, 6, 1, 75-91.

Oliver, R.L., \& Swan, J. (1989). Consumer perceotions of interpersonal equity and satisfaction in transaction: a field survey approach. Journal of consumer research, 16, 372-83. http://dx.doi.org/10.1086/209223

Parasuraman, A., Zeuthaml, V.A., \& Berry, L.L. (1988). A multiple item scale for measuring consumer perceptions of service quality. Journal of retailing, 64, 1, 12-40.

Reichheld, F., \& Schelfter, P. (2000). E-loyalty: your secret weapon on the web. Harvard business review, 78, 4, 105-13.

Rust, R.T., \& Zahorik, A.J. (1993). Customer saticfaction, customer retention, and market share. Journal of retailing, 69, 2, 193-215. http://dx.doi.org/10.1016/0022-4359(93)90003-2

Szymanski, M.D., \& Hise, T.R. (2000). E-satisfaction: an initial examination. Journal of retailing, 76, 3, 309-22. http://dx.doi.org/10.1016/S0022-4359(00)00035-X

Taylor, S., and Peter A. Todd. (1995). Understanding Information Technology User: A Test of Competing Models. Information Systems Research, 6 (June), 144-176. http://dx.doi.org/10.1287/isre.6.2.144

Teo, T. S. H., \& Liu, J. (2007). Consumer trust in e-commerce in the United States, Singapore and 22-China. Omega, 35, 22-38. http://dx.doi.org/10.1016/j.omega.2005.02.001

Trocchia, J.P., \& Janda, S. (2003). How do consumers evaluate internet retail service quality? Journal of services marketing, 17, 3, 243-53. http://dx.doi.org/10.1108/08876040310474800

Wang M. (2003). Assessment of E-Service Quality via E-Satisfaction in E-Commerce Globalization. The Electronic Journal on Information System in Developing Countries, 11, 10, 1-4.

Wang, H., \& Hu, Zh. (2009). Online Trust between Inexperienced Consumers and Experienced Consumers: An Empirical Study. Second International Conference on Future Information Technology and Management Engineering, pp 167-170. http://dx.doi.org/10.1109/FITME.2009.47

Wu, I.L., \& Chen, J.L. (2005). An extention of trust and TAM model with TPB in the initial adoption of online tax:an empirical study. International journal of human computer studies, 62, 784-808. http://dx.doi.org/10.1016/j.ijhcs.2005.03.003

Yaobin, L., \& Tao, Zh. (2007). A research of consumer's initial trust in online stores in China. Journal of research and practice in information technology, 39, 167-180.

Youngwa L., \& Kenneth A. Kozar (2006). Investigating the effect of website quality on e-business success: an analytic hierarchy process(AHP) approach. Decision support systems, 42, 1383-1401. http://dx.doi.org/10.1016/j.dss.2005.11.005 
Zeithaml, V. A. (2000). Service quality, profitability \& the economic worth of customers: what we know and what we need to learn. Journal of the academy of marketing science, 28, 4, 67-85. http://dx.doi.org/10.1177/0092070300281007

\section{Notes}

Note 1. Standard coefficient means double correlation amounts and it is used to compare the effects of model components. Being much higher of this coefficient means more influence of independent variable on dependent variable.

Note 2. Significant number in LISREL software is similar to the concept of "sig" in this software, with the difference that being significant a coefficient, its significant number should be larger than 1.96 or smaller than the -1.96 and it is used to approve or reject research hypotheses. Whatsoever the significant numbers is larger than 1.96, it indicates that independent variable has much stronger effect on dependent variable. (Table 1)

Table 1. Results of structural equation modeling (path analysis)

\begin{tabular}{|l|c|c|}
\hline Relationships & T coefficient & $\begin{array}{c}\beta \\
\text { coefficient }\end{array}$ \\
\hline $\begin{array}{l}\text { electronic service quality - } \\
\text { electronic service confidence }\end{array}$ & -2.34 & -0.23 \\
\hline $\begin{array}{l}\text { electronic service quality - } \\
\text { electronic satisfaction }\end{array}$ & 11.88 & 1.25 \\
\hline $\begin{array}{l}\text { electronic service confidence - } \\
\text { customer behavioral intensions }\end{array}$ & 3.60 & 0.72 \\
\hline $\begin{array}{l}\text { electronic satisfaction - } \\
\text { customer behavioral intensions }\end{array}$ & 9.09 & 0.30 \\
\hline
\end{tabular}

Note: Significant at $\mathrm{p}<0.05$

Based on Table 1, because significant amounts of all hypotheses are higher than 0.96 or less than 1.96, all of the hypotheses were accepted. The highest correlation is between electronic service quality and electronic service satisfaction; the least correlation is between electronic service quality and electronic service confidence.

Table 2. Values of structural model tests

\begin{tabular}{|c|c|}
\hline Chi-square/d.f. & 1.58 \\
\hline RMSEA & 0.069 \\
\hline NFI & 0.91 \\
\hline CFI & 0.89 \\
\hline GFI & 0.92 \\
\hline AGFI & 0.90 \\
\hline
\end{tabular}

Note: Obtained values in the above chart show that the conceptual model has goodness of fit and hypothesis about the causal relationship is approved. Because the mean of squared errors of the model is 0.069 , the model has high goodness of fit. It also indicates that regulated relations between variables, based on the theoretical framework, are logical. 


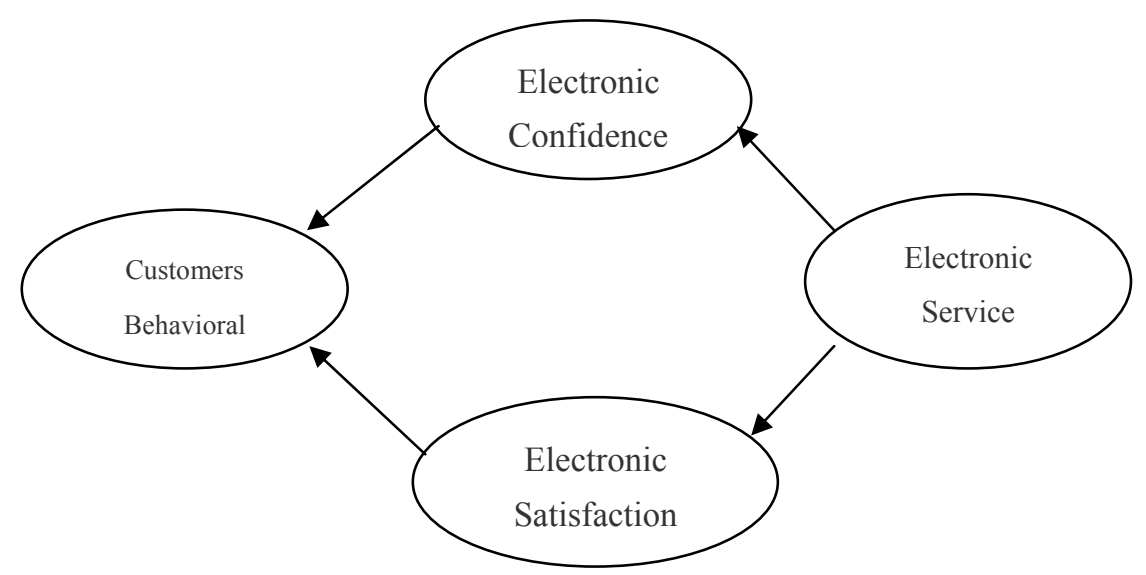

Figure 1. Research conceptual model

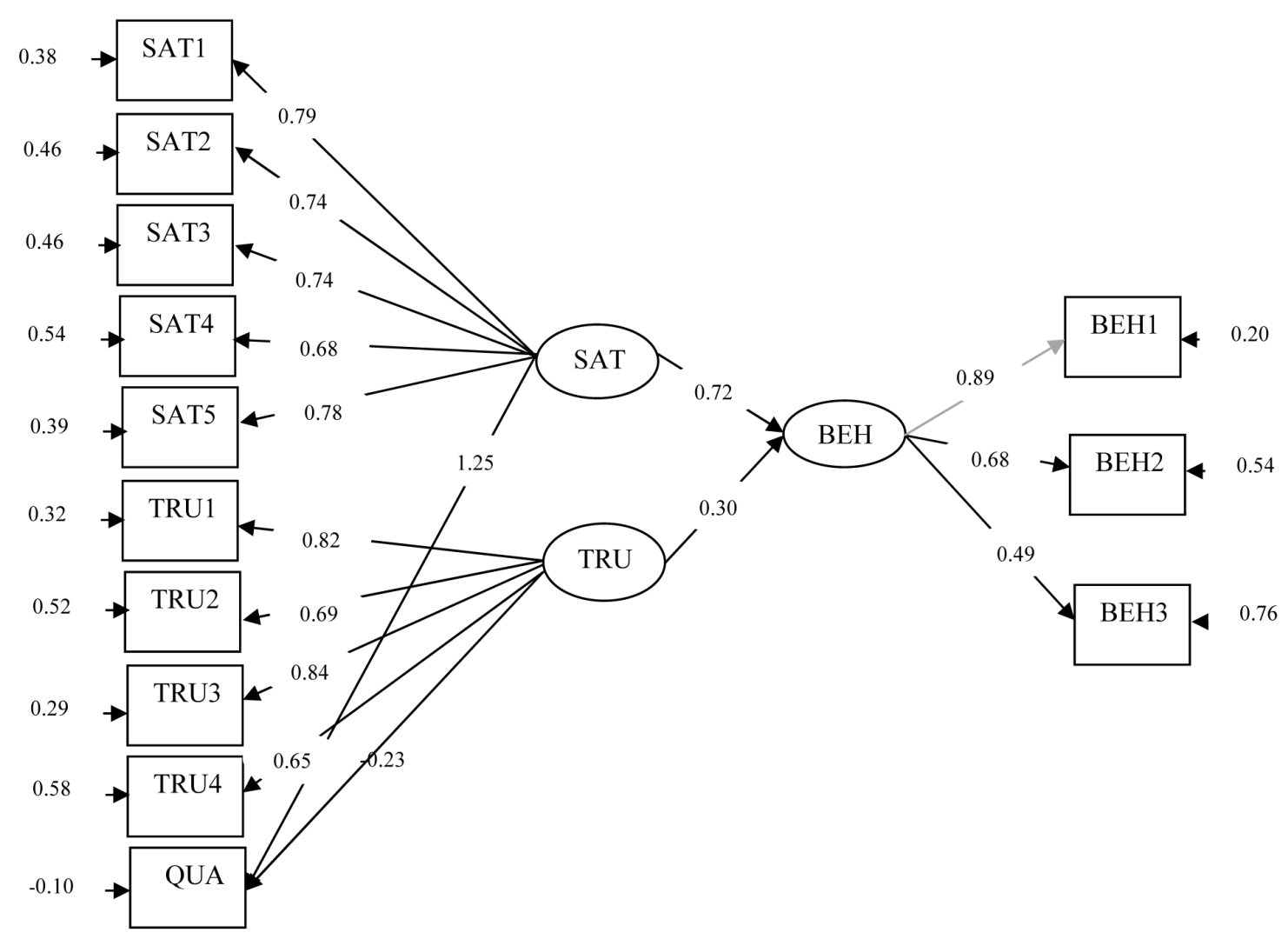

Figure 2. Structural equation modeling (standard estimation)

Note: Chi- Square $=255.6, \mathrm{df}=161, \mathrm{P}$-value $=0.00000, \mathrm{RMSEA}=0.069$ 


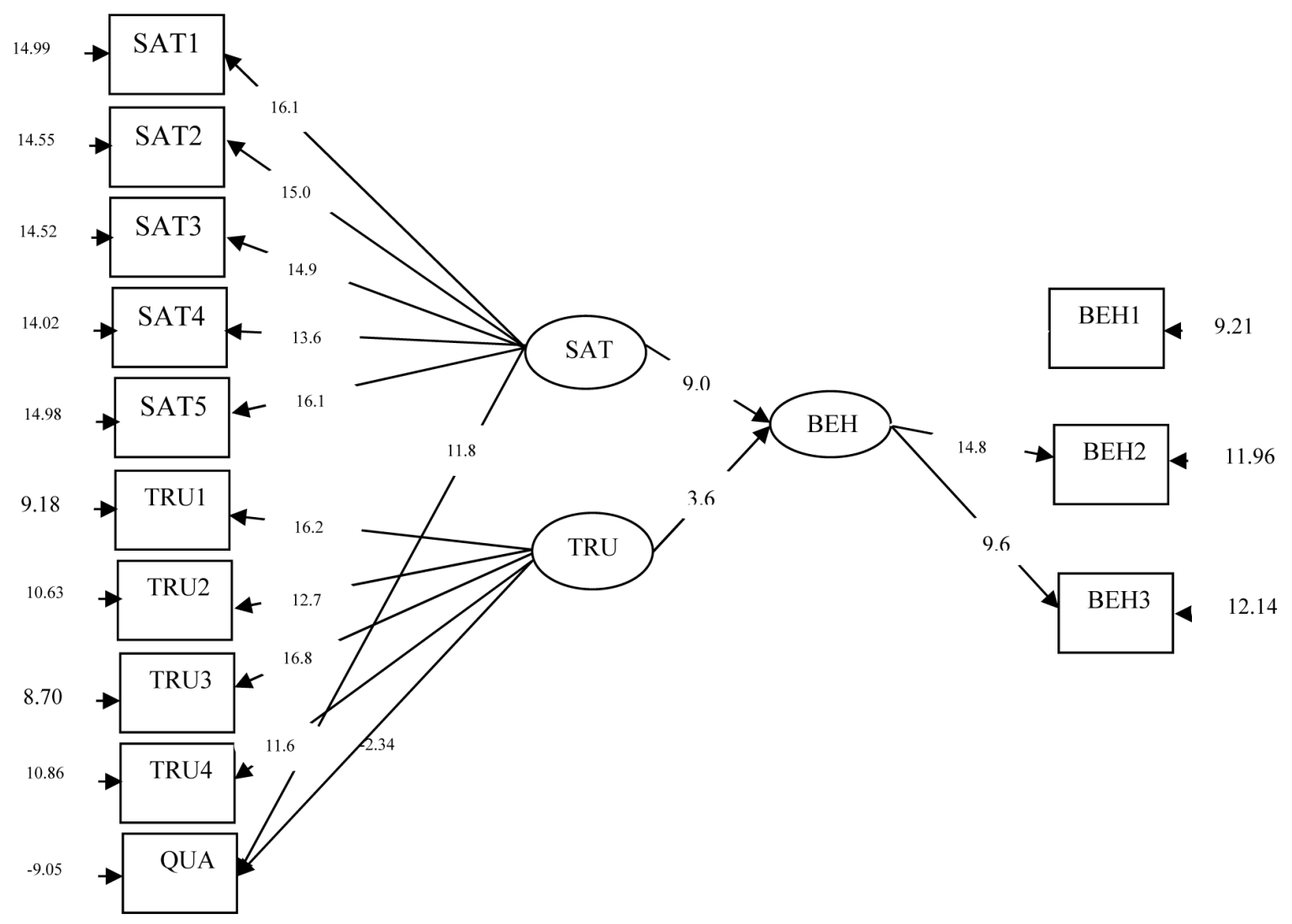

Figure 3. Structural equation modeling (significant number)

Note: Chi- Square $=255.61, \mathrm{df}=161, \mathrm{P}$-value $=0.00000, \mathrm{RMSEA}=0.069$ 